\title{
Uji Efektivitas Ekstrak Daun Tembakau (Nicotiana tabacum L.) terhadap Mortalitas Larva Aedes aegypti
}

\author{
Effectiveness Test Of Extract Tobacco Leaf (Nicotiana tabacum L.) Against Mortality Of \\ Larvae Aedes aegypti
}

\author{
Rochmadina Suci Bestari ${ }^{*}$, Farid Santya Budi ${ }^{1}$, Devi Usdiana Rosyidah ${ }^{1}$, Febrian Dwi Cahyo ${ }^{1}$ \\ ${ }^{1}$ Fakultas Kedokteran Universitas Muhammadiyah Surakarta
}

*Penulis Korespondensi: Rochmadina Suci Bestari. Email :rsb156@ums.ac.id

\begin{abstract}
ABSTRAK
Latar Belakang: Daun tembakau adalah tumbuhan lokal Indonesia yang bermanfaat sebagai larvasida. Daun tembakau mengandung nikotin, alkaloid, saponin, polifenol dan minyak atsiri yang dapat mengakibatkan kematian larva dengan cara merusak sistem saraf dan sistem perncernaan larva. Penelitian ini bertujuan untuk mengetahui daya mortalitas ekstrak daun tembakau (Nicotiana tabacum L.) dalam etanol $96 \%$ terhadap larva Aedes aegypti dan konsentrasi yang efektif untuk membunuh larva.

Metode: Penelitian ini termasuk eksperimental laboratorium murni yaitu memberikan perlakuan ekstrak daun tembakau (Nicotiana tabacum L.) terhadap larva Aedes aegypti dengan metode post test only controlled group design. Terdapat 600 Larva Aedes aegypti instar III secara acak dibagi menjadi 6 kelompok (0,025\%, 0,050\%, $0,075 \%, 0,1 \%$, aquadest + CMC sebagai kontrol negatif serta abate sebagai kontrol positif). Penelitian ini menggunakan 4 pengulangan. Setiap kelompoknya diamati setiap 6 jam selama 24 jam. Hasil uji statistik non parametrik Kruskal-Wallis menunjukkan terdapat perbedaan efek larvasida yang signifikan antar kelompok $(\mathrm{p}=0,000)$.

Hasil: Hasil uji Post Hoc Mann-whitney menunjukkan empat konsentrasi memiliki perbedaan yang signifikan dibandingkan dengan kontrol negatif, sedangkan jika dibandingkan dengan kontrol positif abate, konsentrasi $0,1 \%$ yang berbeda tidak bermakna pada jam ke-24. Hal ini menunjukkan bahwa konsentrasi 0,1\% efektif membunuh larva Aedes aegypti.
\end{abstract}

Kesimpulan: Ekstrak daun tembakau (Nicotiana tabacum L.) efektif dalam membunuh larva Aedes aegypti.

Kata Kunci: Larvasida, Aedes aegypti, Daun Tembakau, Nicotiana tabacum L.

\section{ABSTRACT}

Background: Tobacco leaf can be used as larvaside because it has alkaloid, saponin, polifenol and essential oil which can conduct larva's death by corrupting nervous and dygestive larva's system. This research aims to discover the exterminating power of extract tobacco leaf (Nicotiana tabacum L.) under ethanol 96\% against Aedes aegypti larva and the effective concentration to eradicate larva.

Method: The research is true experimental research that cast tobacco leaf extract (Nicotiana tabacum L.) against Aedes aegypti larva using post test only controlled group design method. There were 600 Aedes aegypti larvas instar III randomly divided into 6 groups $(0,025 \%, 0,050 \%, 0,075 \%, 0,1 \%$, aquadest + CMC as negative control group, and abate as positive control group). The research uses 4 repetition each group was observed every 6 hours for 24 hours.

Results: : Based on statistic test using non parametric Kruskal-Wallis its $p$ value $=0,000$ which mea there was significant effect between groups. Post Hoc Mann-whitney showed four concentratrion groups had significant difference compared with negative control, while there was no difference compared with positive control abate concentration 0,1\% at hour 24. Those showed concentration of $0.1 \%$ effectively kills Aedes aegypti larvae.

Conclusion: Extract tobacco leaf (Nicotiana tabacum L.) effectively kills Aedes aegypti larvae.

Keywords: Larvacide, Aedes aegypti, Tobacco leaf, Nicotiana tabacum L. 


\section{PENDAHULUAN}

Demam Berdarah Dengue (DBD) dan Demam Dengue (DD) merupakan penyakit infeksi yang disebabkan oleh virus dengue yang ditularkan melalui gigitan nyamuk Aedes aegypti dan Aedes albopictus. Penyakit ini dapat menyerang segala usia dengan tanda berupa panas tinggi, perdarahan, dan dapat mengakibatkan kematian, Penyakit ini sering menyebabkan wabah dan prevalensinya terus meningkat setiap tahun. ${ }^{1}$

Indonesia merupakan salah satu negara endemis DBD yang berarti sepanjang tahun selalu didapatkan kejadian DBD di negara ini. ${ }^{2}$ Jumlah kasus DBD di Indonesia terus meningkat dan meluas penyebarannya, diselingi ledakan KLB tiap 5-6 tahun. Hingga pertengahan tahun 2019 ini, demam berdarah memiliki jumlah penderita sebesar 48.905 orang dan 376 orang diantaranya meninggal dunia. Sepanjang 2018, Kemenkes mencatat 90.245 penderita, sementara tahun ini telah mencapai angka 48 ribu di pertengahan tahun, sehingga sangat mungkin angka 90 ribu tersebut dapat dilewati di akhir tahun ini. Di Jawa Tengah, sepanjang tahun 2018, angka kejadian DBD mencapai 16.401 orang. Dari jumlah tersebut, 279 orang diantaranya meninggal dunia dan angka kesakitan sebesar 4,95 per 10.000 penduduk, lebih tinggi dibandingkan tahun 2008 yang hanya sebesar 3,37 per 10.000 penduduk. Data epidemiologi ini menunjukkan bahwa sarana kesehatan sebagai terapi kuratif telah mengalami perbaikan dalam 10 tahun terakhir, namun upaya preventif belum berhasi. ${ }^{3}$

Upaya preventif yang terbukti paling efektif untuk mencegah DBD adalah dengan melakukan pengendalian vektor penyakit ini, yaitu nyamuk, khususnya nyamuk Aedes aegypti. ${ }^{4}$ Pengendalian vektor dapat dilakukan dengan berbagai cara, misalnya program yang disarankan oleh pemerintah adalah Pemberantasan Sarang Nyamuk (PSN) dengan kegiatan 3M plus. kegiatan lain yang mendukung pengendalian vektor, misalnya dengan pemberian larvasida pada tempat penampungan air. ${ }^{5,6}$ Larvasida yang umumnya digunakan di Indonesia adalah larvasida sintetis berupa butiran pasir temephos $1 \%$ yang dikenal dengan nama abate, abate terbukti efektif membunuh larva nyamuk Aedes aegypti dengan angka mortalitas larva mencapai 99-100\%. ${ }^{7}$ Meskipun demikian abate memiliki efek samping terhadap lingkungan, berupa tercemarnya lingkungan serta mengganggu kesehatan makhluk hidup lainnya (selain manusia) yang kontak dengan lingkungan tersebut. ${ }^{8}$

Banyak penelitian yang menunjukkan efek larvasida dari berbagai tanaman salah satunya tanaman tembakau, tembakau dapat digunakan sebagai larvasida karena daun tembakau memiliki kandungan alkaloid, saponin, polifenol dan minyak atsiri. Senyawa-senyawa ini merupakan racun kontak yang dapat mengakibatkan kematian pada larva nyamuk dengan cara merusak sistem saraf dan sistem perncernaan larva nyamuk. ${ }^{9}$

Dari uraian di atas, maka peneliti merasa tertarik untuk mengetahui daya bunuh ekstrak daun tembakau (Nicotiana tabacum L) terhadap larva Aedes aegypti dengan menggunakan dengan menggunakan etanol $96 \%$ guna mencari konsentrasi yang paling efekif terhadap kematian larva.

\section{METODE}

Penelitian ini termasuk eksperimental laboratorium menggunakan metode post test only with controlled group design. Penelitian dilaksanakan di Sublab Farmakologi FK UMS dan Balai Besar Penelitian dan Pengembangan Vektor dan Reservoir Penyakit (B2P2VRP) Salatiga, Jawa Tengah. Subjek yang digunakan dalam penelitian ini adalah larva Aedes aegypti instar III.

Daun tembakau (Nicotiana tabacum L.) yang sudah dikeringkan kemudian dihaluskan hingga berbentuk serbuk, kemudian ditimbang 1000 gram daun tembakau (Nicotiana 
tabacum L.) dan ditambahkan pelarut etanol 96\% dengan rasio bahan pelarut 1:3 untuk proses maserasi. Hasil kedua bahan yang dicampur tersebut diaduk selama 10 menit, lalu didiamkan selama 3x24 jam kemudian disaring untuk memisahkan filtrat dan residu. Filtrat diuapkan dengan Vacuum Rotary Evaporator dan dipanaskan dengan pemanas waterbath dalam suhu $60^{\circ} \mathrm{C}$, kemudian dituang ke cawan porselin dan didapatkan ekstrak. Ekstrak dipanaskan pada waterbath dengan suhu $60^{\circ} \mathrm{C}$ dalam kondisi diaduk secara terus menerus. Hasil dari pemanasan tersebut, didapatkan ekstrak murni dengan kandungan 100\% dan siap digunakan.

Uji penelitian menggunakan 750 ekor larva dimana 150 ekor larva untuk uji pendahuluan dan 600 ekor larva untuk uji penelitian. Uji pendahuluan tidak dilakukan pengulangan dan uji penelitian diulang sebanyak 4 kali sesuai rumus Federer.

Kontrol positif (diberi abate), kontrol negatif (diberikan Aquadest $+\mathrm{CMC}$ ), P1 (konsentrasi ekstrak daun tembakau 0,025
\%), P2 (konsentrasi ekstrak daun tembakau 0,050\%), P3 (konsentrasi ekstrak daun tembakau 0,075\%), dan P4 (konsentrasi ekstrak daun tembakau 0,100\%), berlangsung selama 24 jam dengan empat pengulangan dan diamati setiap 6 jam. Larva yang mati ditandai dengan larva tidak bergerak meski disentuh dengan lidi. Larva yang mati diambil menggunakan pipet dan dipisahkan dari kelompok. Jumlah larva yang mati dihitung tiap 6 jam.

Analisis data dilakukan secara bertahap, yaitu diawali dengan uji normalitas dengan uji Saphiro-Wilk dan varians homogen (diuji dengan Levene test), perbedaan pada setiap variabel perlakuan terhadap kematian nyamuk akan dianalisis dengan menggunakan uji Kruskal Wallis. Selanjutnya dilakukan uji lanjut post-hoc dengan Mann Whitney. Selain itu juga dilaksanakan uji analisis probit.

\section{HASIL DAN PEMBAHASAN}

Hasil

Tabel 1. Jumlah kematian larva Aedes aegypti pada jam ke 6-24 dengan pemberian ekstrak daun tembakau (Nicotiana tabacum L.)

\begin{tabular}{|c|c|c|c|c|c|c|c|}
\hline \multirow{4}{*}{$\begin{array}{l}\text { Perlakukan/ } \\
\text { Konsentrasi }\end{array}$} & \multirow{4}{*}{ Pengulangan } & \multicolumn{4}{|c|}{ Kematian Larva Setelah Diberi Ekstrak } & \multirow{4}{*}{$\begin{array}{l}\text { Rata-Rata } \\
\text { Kematian } \\
\text { pada jam } \\
\text { ke- } 24 \pm \text { SD }\end{array}$} & \multirow{4}{*}{$\begin{array}{c}\text { Persentase } \\
\text { Kematian } \\
\text { pada jam } \\
\text { ke-24 }\end{array}$} \\
\hline & & \multicolumn{4}{|c|}{ Daun Tembakau } & & \\
\hline & & Jam & Jam & Jam & Jam & & \\
\hline & & Ke-6 & $\mathrm{Ke}-12$ & Ke-18 & $\mathrm{Ke}-24$ & & \\
\hline \multirow{4}{*}{$\begin{array}{c}\text { P0 } \\
\text { (KONTROL -) }\end{array}$} & I & 0 & 0 & 0 & 0 & \multirow{5}{*}{$0 \pm 0$} & \multirow{5}{*}{$0 \%$} \\
\hline & II & 0 & 0 & 0 & 0 & & \\
\hline & III & 0 & 0 & 0 & 0 & & \\
\hline & IV & 0 & 0 & 0 & 0 & & \\
\hline \multicolumn{2}{|c|}{ Rata-Rata Kematian Perwaktu } & 0 & 0 & 0 & 0 & & \\
\hline \multirow{4}{*}{$\mathrm{P} 1(0,025 \%)$} & $\mathrm{I}$ & 0 & 4 & 6 & 7 & \multirow{5}{*}{$8 \pm 0,81$} & \multirow{5}{*}{$32 \%$} \\
\hline & II & 0 & 6 & 8 & 9 & & \\
\hline & III & 1 & 7 & 7 & 8 & & \\
\hline & IV & 0 & 5 & 6 & 8 & & \\
\hline Rata-Rata Kem & tian Perwaktu & 0.25 & 5.5 & 6.75 & 8 & & \\
\hline \multirow{4}{*}{$\mathrm{P} 2(0,050 \%)$} & I & 2 & 8 & 13 & 17 & \multirow{5}{*}{$16.25 \pm 1,5$} & \multirow{5}{*}{$65 \%$} \\
\hline & II & 0 & 7 & 12 & 18 & & \\
\hline & III & 0 & 7 & 12 & 15 & & \\
\hline & IV & 1 & 8 & 11 & 15 & & \\
\hline Rata-Rata Kem & tian Perwaktu & 0.75 & 7.5 & 12 & 16.25 & & \\
\hline
\end{tabular}


Tabel 2. Jumlah kematian larva Aedes aegypti pada jam ke 6-24 dengan pemberian ekstrak daun tembakau (Nicotiana tabacum L.)

\begin{tabular}{|c|c|c|c|c|c|c|c|}
\hline \multirow{2}{*}{ Perlakukan/Konsentrasi } & \multirow{2}{*}{ Pengulangan } & \multicolumn{4}{|c|}{$\begin{array}{c}\text { Kematian Larva Setelah Diberi } \\
\text { Ekstrak Daun Tembakau }\end{array}$} & \multirow{2}{*}{$\begin{array}{c}\text { Rata-Rata } \\
\text { Kematian } \\
\text { pada jam } \\
\text { ke-24 } \pm \\
\text { SD }\end{array}$} & \multirow{2}{*}{$\begin{array}{c}\text { Persentase } \\
\text { Kematian } \\
\text { pada jam } \\
\text { ke-24 }\end{array}$} \\
\hline & & $\begin{array}{c}\text { Jam } \\
\mathrm{Ke}-6\end{array}$ & $\begin{array}{c}\text { Jam } \\
\text { Ke-12 }\end{array}$ & $\begin{array}{c}\text { Jam } \\
\text { Ke-18 }\end{array}$ & $\begin{array}{c}\text { Jam } \\
\text { Ke-24 }\end{array}$ & & \\
\hline \multirow{4}{*}{ P3 $(0,075 \%)$} & I & 5 & 16 & 19 & 20 & \multirow{5}{*}{$21 \pm 0,81$} & \multirow{5}{*}{$84 \%$} \\
\hline & II & 4 & 18 & 19 & 21 & & \\
\hline & III & 3 & 16 & 18 & 22 & & \\
\hline & IV & 3 & 14 & 17 & 21 & & \\
\hline Rata-Rata Kematiar & Perwaktu & 3.75 & 16 & 18.25 & 21 & & \\
\hline \multirow{4}{*}{ P4 $(0,100 \%)$} & $\mathrm{I}$ & 6 & 23 & 25 & 25 & \multirow{5}{*}{$24.75 \pm 0,5$} & \multirow{5}{*}{$99 \%$} \\
\hline & II & 5 & 23 & 24 & 25 & & \\
\hline & III & 7 & 21 & 24 & 24 & & \\
\hline & IV & 6 & 20 & 25 & 25 & & \\
\hline Rata-Rata Kematiar & Perwaktu & 6 & 21.75 & 24.5 & 24.75 & & \\
\hline \multirow{4}{*}{ P6 (KONTROL +) } & I & 25 & 25 & 25 & 25 & \multirow{5}{*}{$25 \pm 0$} & \multirow{5}{*}{$100 \%$} \\
\hline & II & 25 & 25 & 25 & 25 & & \\
\hline & III & 25 & 25 & 25 & 25 & & \\
\hline & IV & 25 & 25 & 25 & 25 & & \\
\hline Rata-Rata Kematiar & Perwaktu & 25 & 25 & 25 & 25 & & \\
\hline
\end{tabular}

(Sumber: Data Primer, 2018)

Dilihat pada Tabel 1 tidak dijumpai adanya kematian larva Aedes aegypti pada kelompok kontrol negatif, sedangkan angka kematian tertinggi untuk kelompok perlakuan dijumpai pada konsentrasi $0,100 \%$.

Hasil penelitian ini menunjukkan bahwa semakin tinggi konsentrasi ekstrak daun tembakau (Nicotiana tabacum L.) yang diberikan maka semakin tinggi pula jumlah larva Aedes aegypti yang mati.

Uji normalitas dengan Shapiro-wilk menunjukkan bahwa salah satu kelompok didapatkan hasil $\mathrm{p}=0,001 \quad(<0,05)$ yang menandakan distribusi data tidak normal. Uji homogenitas menggunakann Levene test didapatkan nilai p 0,003 (< 0,05$)$, sehingga dapat diasumsikan data tidak homogen. Lalu untuk menganalisis perbedaan pengaruh pemberian konsentrasi ekstrak daun tembakau (Nicotiana tabacum L.) dalam etanol $96 \%$ terhadap kematian larva Aedes aegypti dilakukan uji statistik non parametrik Kruskall - Wallis, menunjukkan nilai signifikansi $\mathrm{p}=0,000(<$ $0,05)$, yaitu terdapat perbedaan yang bermakna antara setiap kelompok perlakuan.

Selanjutnya dilakukan uji post hoc yang digunakan adalah Mann - Whitney Tes dapat dilihat di Tabel 2.

Tabel 3. Hasil Uji Post Hoc Mann-Whitney

\begin{tabular}{cc}
\hline Kelompok & Nilai $p$ \\
\hline K- dengan P1 & $0,013^{*}$ \\
K- dengan P2 & $0,013^{*}$ \\
K- dengan P3 & $0,013^{*}$ \\
K- dengan P4 & $0,011^{*}$ \\
K- dengan K+ & $0,008^{*}$ \\
P1 dengan P2 & $0,019^{*}$ \\
P1 dengan P3 & $0,019^{*}$ \\
\hline
\end{tabular}


Tabel 4. Hasil Uji Post Hoc Mann-Whitney

\begin{tabular}{cc}
\hline Kelompok & Nilai $p$ \\
\hline P1 dengan P4 & $0,017^{*}$ \\
P1 dengan K+ & $0,013^{*}$ \\
P2 dengan P3 & $0,019^{*}$ \\
P2 dengan P4 & $0,017^{*}$ \\
P2 dengan K+ & $0,013^{*}$ \\
P3 dengan P4 & $0,017^{*}$ \\
P3 dengan K+ & $0,013^{*}$ \\
P4 dengan K+ & 0,317 \\
\hline
\end{tabular}

*berbeda bermakna $(\mathrm{p}<0,05)$

(Sumber: Data Primer, 2019)

Nilai LC50 ditentukan berdasarkan jumlah kematian larva uji yang didapatkan pada masing-masing konsentrasi. Berikut disajikan nilai LC50 pada tiap waktu pengamatan berdasarkan analisis probit.

Data yang diperoleh pada Tabel 3 menunjukan nilai LC50 dan LC90 semakin menurun saat pertama pengamatan dimulai pada jam ke-6 hingga pada pengamatan Jam ke-24. Hal ini menunjukan bahwa semakin lama pajanan yang menimbulkan kematian larva $50 \%$ dan $90 \%$ dari total larva uji, maka dibutuhkan konsentrasi yang semakin sedikit. Hasil dari analisis probit lethal concentration yang dilakukan pada masing-masing waktu pengamatan, terlihat nilai LC50 hingga jam ke-24 membutuhkan konsentrasi 0,052\%.

Tabel 5. Nilai $\mathrm{LC}_{50}$ dan LC $\mathrm{L}_{90}$ larva Aedes aegypti.

LT50 adalah lama waktu yang dibutuhkan untuk menyebabkan larva mati sebesar $50 \%$ dari total larva uji. LT50 dipergunakan untuk mengetahui efektivitas suatu larvasida untuk diaplikasikan dalam waktu 24 jam. Berdasarkan uji probit didapatkan nilai LT50 pada masing-masing konsentrasi perlakuan seperti pada tabel berikut:

Tabel 6. Nilai $\mathrm{LT}_{50}$ larva Aedes aegypti pada berbagai konsentrasi

\begin{tabular}{ccc}
\hline No. & Konsentrasi $(\%)$ & LT50 (Jam) \\
\hline 1 & 0,025 & 37.084 \\
2 & 0,050 & 16.158 \\
3 & 0,075 & 9.580 \\
\hline
\end{tabular}


Tabel 6. Nilai $\mathrm{LT}_{50}$ larva Aedes aegypti pada berbagai konsentrasi

\begin{tabular}{ccc}
\hline No. & Konsentrasi $(\%)$ & LT50 $(\mathrm{Jam})$ \\
\hline 4 & 0,100 & 6.826 \\
\hline \multicolumn{3}{c}{ (Sumber: Data Primer, 2019) }
\end{tabular}

Berdasarkan hasil analisis, didapatkan adanya penurunan $\mathrm{LT}_{50}$ dari konsentrasi terendah ekstrak daun tembakau $(0,025 \%)$ sampai konsentrasi tertingginya $(0,100 \%)$. Data tersebut menunjukan bahwa semakin besar konsentrasi yang diberikan maka semakin cepat pula waktu yang dibutuhkan untuk membunuh 50\% larva. Pada konsentrasi $0,025 \%$ memiliki nilai $\mathrm{LT}_{50}$ yang melebihi batas waktu pengamatan yaitu 24 jam.

\section{PEMBAHASAN}

Tanaman telah dianjurkan sebagai salah satu senjata ampuh untuk mengendalikan spesies serangga. Salah satu keuntungannya adalah efikasi yang tinggi pada ekstrak tumbuhan di berbagai negara sedang berkembang, terhadap pengendalian nyamuk. Negara itu termasuk Indonesia. Salah satu tanaman yang bisa digunakan untuk pengendalian nyamuk itu adalah tembakau. ${ }^{10}$

Di kelompok kontrol (-), tidak terdapat larva Aedes aegypti yang mati. Pada kelompok perlakuan dengan konsentrasi $0,100 \%$ terlihat angka kematian tertinggi, kematian larva mengalami peningkatan mulai dari konsentrasi terendah $(0,025 \%)$ hingga konsentrasi tertinggi $(0,100 \%)$. Dari hasil penelitian itu, dapat diketahui bahwa semakin tinggi konsentrasi ekstrak daun tembakau (Nicotiana tabacum L.) dalam etanol $96 \%$ yang diberikan maka semakin tinggi pula jumlah larva Aedes aegypti yang mati. Hasil penelitian Hikmah (2018) tentang uji efektivitas daun tembakau terhadap kematian larva Aedes aegypti pun menunjukkan hal tersebut. ${ }^{11}$ Analisis Ardhyarini (2017) dengan uji korelasi Pearson menunjukkan adanya korelasi kuat antara peningkatan konsentrasi ekstrak daun tembakau (Nicotiana tabacum L.) dengan kematian nyamuk dewasa. $^{12}$

Penelitian Wijayanti dkk (2015) menunjukan bahwa semakin tinggi konsentrasi ekstrak daun tembakau (Nicotiana tabacum L. maka semakin tinggi pula efek larvasidanya. ${ }^{13}$ Hal tersebut disebabkan karena adanya kandungan senyawa nikotin, saponin, alkaloid, polifenol dan minyak atsiri. Nikotin berfungsi sebagai racun yang dapat mempengaruhi sistem pencernaan dan sistem saraf larva sedangkan senyawasenyawa lain dapat berfungsi merusak sistem pernafasan dan saluran cerna. ${ }^{10,12}$

Penelitian ini menunjukkan dosis yang paling efektif adalah konsentrasi 0,1\%. Penelitian sebelumnya menggunakan filtrat daun tembakau kering menyimpulkan dosis paling efektif adalah $0,25 \% .{ }^{14}$

Kelompok perlakuan yang diberi ekstrak daun tembakau dapat diketahui pada kelompok $\mathrm{K}$ - yang dibandingkan dengan kelompok P1, P2, P3, dan P4 memiliki nilai $p$ yang berbeda bermakna, dan pada kelompok P4 yang dibandingkan dengan $\mathrm{K}+$ memiliki nilai $\mathrm{p}$ yang tidak berbeda bermakna.

Hal ini disebabkan perbedaan tingkat kematian larva bervariasi pada kelompok Kjika dibandingkan dengan kelompok P1, P2, P3, P4, dan $\mathrm{K}+$. Hal ini dikarenakan tingkat konsentrasi yang diberikan pada setiap kelompok perlakuan memiliki perbedaan yang signifikan dan dapat diketahui bahwa semakin tinggi konsentrasi maka semakin tinggi tingkat kematian larva. Oleh sebab itu kelompok P4 yang memiliki tingkat persentase kematian tertinggi yaitu $99 \%$ lebih efektif dari pada kelompok P1, P2, dan P3 yang tingkat rerata kematian dibawah P4. Pada kelompok K+ (abate) 
jika dibandingkan dengan kelompok P4 mempunyai kekuatan yang hampir sama untuk membunuh larva. Karena pada konsentrasi $0,100 \%$ ekstrak daun tembakau mengandung senyawa optimal yang dapat membunuh larva. Kematian larva disebabkan oleh senyawa nikotin sebagai racun utama. Larvasida berbahan aktif nikotin bekerja pada sistem saraf. Bahan aktif tersebut menghambat enzim asetilkolinesterase sehingga terjadi penumpukan asetilkolin lalu menimbulkan kekacauan dalam menghantarkan impuls saraf. Dalam hal ini, larva tidak mampu mendetoks bahan aktif berupa racun tersebut. ${ }^{13,15}$

Berdasarkan hasil uji probit lethal concentration menunjukkan bahwa nilai $\mathrm{LC}_{50}$ yaitu konsentrasi ekstrak daun tembakau (Nicotiana tabacum L.) yang dibutuhkan untuk membunuh larva Aedes aegypti sebesar $50 \%$ dalam waktu 6, 12, 18 dan 24 jam secara berturut-turut adalah $0,148 \%, 0,073 \%, 0,064 \%$ dan $0,052 \%$. Sementara itu nilai $\mathrm{LC}_{90}$ yaitu konsentrasi ekstrak daun tembakau (Nicotiana tabacum L.) yang dapat menyebabkan kematian larva Aedes aegypti sebesar $90 \%$ dalam waktu 6, 12,18 dan 24 jam secara berturut-turut yaitu 0,313\%，0,110\%，0,093\% dan 0,085\%. Berdasarkan hasil uji probit antara $\mathrm{LC}_{50}$ dengan $\mathrm{LC}_{90}$, dapat diketahui bahwa semakin tinggi konsentrasi ekstrak daun tembakau (Nicotiana tabacum L.), maka semakin tinggi pula jumlah kematian larva Aedes aegypti. Hal ini dikarenakan semakin besar konsentrasi ekstrak daun tembakau, maka semakin besar pula jumlah kandungan senyawa yang memiliki efek larvasida sehingga dapat mematikan larva uji. ${ }^{16}$ Penelitian yang pernah dilakukan sebelumnya oleh Indriyani (2008) menggunakan rebusan daun tembakau, LD50 sebesar 0,9 $\mathrm{ml}$, artinya dengan dosis $0,9 \mathrm{ml}$ bisa membunuh larva sebanyak $50 \%{ }^{17}$

Hasil Uji probit $\mathrm{LT}_{50}$ yaitu waktu yang dibutuhkan ekstrak daun tembakau (Nicotiana tabacum L.) dalam membunuh larva Aedes aegypti sebesar 50\% larva dengan konsentrasi $0,025 \%, 0,050 \%$,
$0,075 \%$ dan $0,100 \%$ secara berturut-turut membutuhkan waktu selama 37.084 jam, 16.158 jam, 9.580 jam dan 6.826 jam. Sehingga pemberian ekstrak daun tembakau (Nicotiana tabacum L.) dari segi waktu efektif jika dipakai sebagai larvasida. Berdasarkan hasil uji probit lethal concentration dan lethal time, dapat diketahui bahwa semakin tinggi konsentrasi yang diberikan pada larva uji, maka semakin banyak bahan aktif racun yang terpajan pada larva uji, sehingga waktu yang dibutuhkan untuk menyebabkan larva mati menjadi semakin cepat.

Mittai et al menyebutkan bahwa tembakau mengandung nikotin, tar dan karbonmonoksida sebagai komponen utama, yang bervariasi konsentrasinya pada bagianbagian tumbuhan yang berbeda. Dari semua komponen tersebut, nikotin adalah kandungan yang paling efektif sebagai insektisida. Kandungan ini bersifat biodegradable secara sempurna. Selain menyebabkan kerusakan saraf, komponen ini juga menyebabkan kerusakan pada organ perut. Karbon monoksida menjadi racun yang menyebabkan serangga tercekik dan mati. Larva adalah stadium nyamuk yang paling susceptible untuk dipajan racun tembakau ini, dibandingkan stadium-stadium lain yaitu telur, pupa dan nyamuk dewasa. Sehingga memang ekstrak daun tembakau paling sesuai dijadikan larvasida daripada insektisida untuk membunuh telur, pupa maupun nyamuk dewasa. ${ }^{10}$ Upaya mengontrol nyamuk ini diharapkan untuk bisa mengendalikan angka insidensi Demam Berdarah Dengue di Indonesia.

\section{KESIMPULAN}

Terdapat pengaruh ekstrak daun tembakau (Nicotiana tabacum L.) dalam pelarut etanol $96 \%$ terhadap mortalitas larva Aedes aegypti. Dosis efektif ekstrak daun tembakau (Nicotiana tabacum L.) dalam membunuh larva Aedes aegypti yaitu konsentrasi $0,1 \%$. 


\section{DAFTAR PUSTAKA}

1. Sudoyo, A. Buku ajar ilmu penyakit dalam edisi v. Jakarta: PPDS FKUI.2014

2. WHO.Dengue and severe dengue, WHO International Media Factsheet. 2016.

3. Kementerian Kesehatan RI. 2018. Riset kesehatan dasar tahun 2018. Tersedia di: URL: HIPERLINK http: // labdata.litbang.depkes.go.id/riset-badanlitbangkes/menu-riskesnas/menuriskesdas

4. Azlina A, Adrial, Anas E. Hubungan tindakan pemberantasan sarang nyamuk dengan keberadaan larva vektor dbd di kelurahan lubuk buaya. Jurnal Kesehatan Andalas. 2016;5(1):221-227.

5. Septianto A. 2014 Hubungan antara praktik pemberantasan sarang nyamuk (PSN) dengan keberadaan jentik nyamuk aedes aegypti di rw 7 kelurahan sukorejo keca-matan gunungpati kota semarang. [Skripsi] Semarang: Universitas Negeri Semarang.

6. Bestari RS. Siahaan PP. Hubungan tingkat pengetahuan dan perilaku mahasiswa tentang pemberantasan sarang nyamuk (PSN) demam berdarah dengue (DBD) terhadap keberadaan jentik aedes aegypti. Jurnal Biomedika. 2018;10(1)

7. George L. Toledo J. Lenhart A. Community - effectiveness of temephos for dengue vector control: a systematic literature review. PLoS Neglected Tropical Diseases. 2015;9(9):1-22.

8. Vasantha SP. Senthil NS. Ponsankar A. Thanigaivel A. 2017. Comparative analysis of mosquito (diptera: culicidae: aedes aegypti liston) responses to the insecticide temephos and plant derived essential oil derived from piper betle 1 . Ecotoxicology and Environmental Safety. 139:439-446.

9. Handayani SW, Prastowo D, Boesri H, Oktsariyanti A, Joharina AS. Efektivitas ekstrak daun tembakau (nicotiana tabacum 1) dari semarang, temanggung, dan kendal sebagai larvasida aedes aegypti 1. Balaba: Jurnal Litbang Pengendalian Penyakit Bersumber Binatang Banjarnegara. 2018;14(1):2330

10. Ileke KD, Oyeniyi EA, Ogungbite OC. et al. Nicotiana tabacum a prospective mosquitocide in management of anopheles gambiae (giles). IJMR. 2015; 2(4): 19-23

11. Hikmah N. Uji efektifitas ekstrak daun tembakau dan tembakau pada rokok terhadap kematian larva aedes aegypti. Respository Unimus. 2018.

12. Ardhyarini SI. 2017. Efek ekstrak daun tembakau (nicotiana tabacum 1.) sebagai insektisida alami terhadap stadium dewasa nyamuk culex sp. [Skripsi]. Malang: Universitas Muhammadiyah Malang.

13. Wijayanti MP, Yuliawati S, Hestiningsih R. Uji toksisitas daun tembakau (nicotiana tabacum 1.) dengan metode maserasi terhadap mortalitas culex quinquefasciatus. Jurnal Kesehatan Masyarakat. 2015;3(1):143-151.

14. Prasetyo EH. 2004. Pengaruh konsentrasi filtrat daun tembakau (nicotiana tabacum 1.) kering terhadap jumlah kematian larva nyamuk aedes aegypti. [Skripsi]. Universitas Muhammadiyah Malang.

15. Yunita EA, Suprapti NH, Hidayat JW. Pengaruh ekstrak daun teklan (eupatorium riparium) terhadap mortalitas dan perkembangan larva aedes aegypti. BIOMA. 2009; 11(1):11-17.

16. Minarni E, Armansyah T, Hanafiah A. Daya larvasida perasan etil asetat daun kemuning (murraya paniculata (l) jack) terhadap larva nyamuk aedes aegypti, jurnal medical veterinaria. 2013;7(1):2729.

17. Indriyani Y, 2008. Daya mematikan air rebusan daun tembakau (nicotiana tabacum 1.) terhadap larva nyamuk aedes aegypti 1. di laboratorium. [Skripsi]. Semarang: Universitas Diponegoro. 